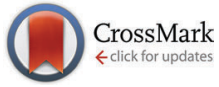

Cite this: Chem. Commun., 2014, 50, 12050

Received 17th July 2014,

Accepted 23rd August 2014

DOI: $10.1039 / c 4 c c 05519 e$

www.rsc.org/chemcomm

\section{Highly effective yet simple transmembrane anion transporters based upon ortho-phenylenediamine bis-ureas $\dagger$}

\author{
Louise E. Karagiannidis, ${ }^{a}$ Cally J. E. Haynes, ${ }^{a}$ Katie J. Holder, ${ }^{a}$ Isabelle L. Kirby, ${ }^{a}$ \\ Stephen J. Moore, ${ }^{a}$ Neil J. Wells ${ }^{a}$ and Philip A. Gale*ab
}

\begin{abstract}
Simple, highly fluorinated receptors are shown to function as highly effective transmembrane anion antiporters with the most active transporters rivalling the transport efficacy of natural anion transporter prodigiosin for bicarbonate.
\end{abstract}

The transport of ions, and in particular chloride and bicarbonate anions, across cell membranes is important to numerous biological processes, and is often mediated by proteins embedded within cellular lipid bilayers. ${ }^{1}$ Malfunction of these proteins, through genetic mutation or otherwise, can lead to diseases such as cystic fibrosis. ${ }^{1}$ With this in mind, much focus is being placed on the development of small synthetic molecules that can mimic the role of such proteins. With the potential to bind or encapsulate ions, such synthetic "carriers" could be developed for therapeutic applications. $^{2}$

The prodigiosin family of compounds are highly potent natural anionophores, produced by bacteria from the Streptomyces and Serratia genera. ${ }^{3}$ Prodigiosins have been shown to symport $\mathrm{H}^{+} / \mathrm{Cl}^{-4,5}$ and function as $\mathrm{Cl}^{-} / \mathrm{NO}_{3}{ }^{-6}$ and $\mathrm{Cl}^{-} / \mathrm{HCO}_{3}{ }^{-7}$ antiporters, demonstrating an ability to act as antibiotic and anticancer agents, as well as exhibiting immunosuppressive behaviour. ${ }^{8}$ Prodigiosin itself, 8, is amongst the most potent anion transporters known. ${ }^{7}$

Synthetic approaches to the design of anion transporters include the attachment of hydrogen bond donor groups to a lipophilic scaffold, an approach to anion transporter design pioneered by Davis and co-workers, with the development of cholic acid derived transporters and more recently systems based upon decalin and cyclohexane. ${ }^{9}$ Our approach has focused on developing new hydrogen bonding arrays for transport, with

\footnotetext{
${ }^{a}$ Chemistry, University of Southampton, Southampton, SO17 1BJ, UK.

E-mail: philip.gale@soton.ac.uk

${ }^{b}$ Department of Chemistry, Faculty of Science, King Abdulaziz University, Jeddah 21589, Saudi Arabia

$\dagger$ Electronic supplementary information (ESI) available: Details of receptor synthesis, characterisation, anion transport and anion binding studies as well as additional X-ray diffraction information. CCDC 1004419-1004421. For ESI and crystallographic data in CIF or other electronic format see DOI: 10.1039/c4cc05519e
}

systems containing thiourea, squaramide and thiosquaramide groups showing excellent anion transport properties. ${ }^{10}$ Recently we began to study the anion transport properties of bis-urea receptors based on ortho-phenylenediamine, a system that we developed as an anion receptor in $2005 .{ }^{11}$ We found that these compounds had excellent anion transport properties but in our initial study the compounds (including compounds $\mathbf{1}$ and 5) ${ }^{12}$ had not been optimised for transport. Here we report a more complete series of ortho-phenylenediamine-based bis ureas functionalised with $\mathrm{NO}_{2}, \mathrm{~F}, \mathrm{CF}_{3}$ and $\mathrm{SF}_{5}{ }^{13}$ groups that are structurally simple, can be synthesised in one step and yet possess exceptional anion transport properties (i.e. low $\mathrm{EC}_{50}$ values - see below) some of which are more effective chloride/bicarbonate antiport agents than the natural product prodigiosin.,14

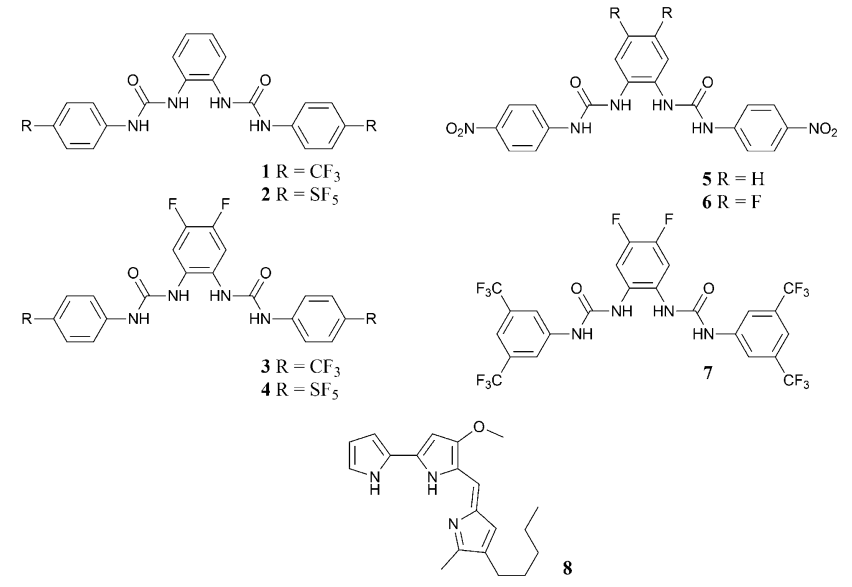

We have previously reported the synthesis and transport properties of receptors 1 and $5 .^{11,12}$ Reaction of 1,1'-carbonyl diimidazole (CDI) with 4-aminophenyl sulfur pentafluoride and the appropriately functionalised ortho-phenylenediamine in dichloromethane yielded receptors 2 ( $86 \%$ yield) and 4 (23\% yield). Reaction of the appropriate isocyanate with the appropriately substituted phenylenediamine in a mixture of dichloromethane and pyridine gave compounds 3, 6 and 7 in $68 \%, 59 \%$ and $32 \%$ yields respectively. 


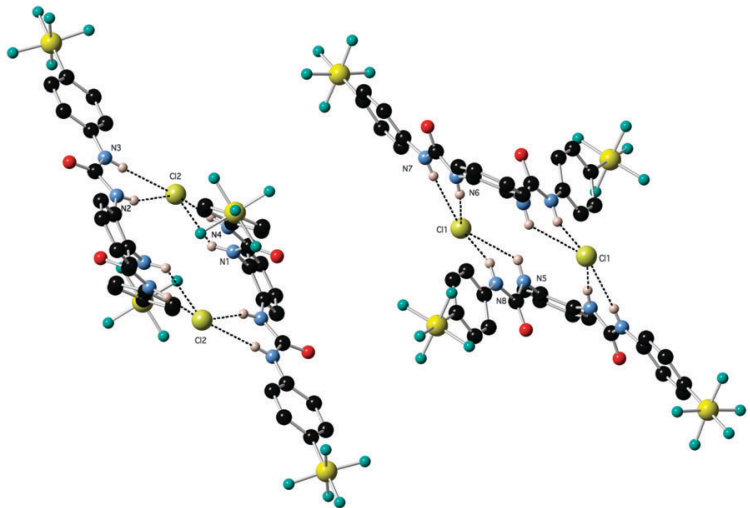

Fig. 1 X-ray crystal structure of 2.TBACl showing the packing arrangement Counter ions, DMSO solvent and non-acidic hydrogen atoms have been omitted for clarity.

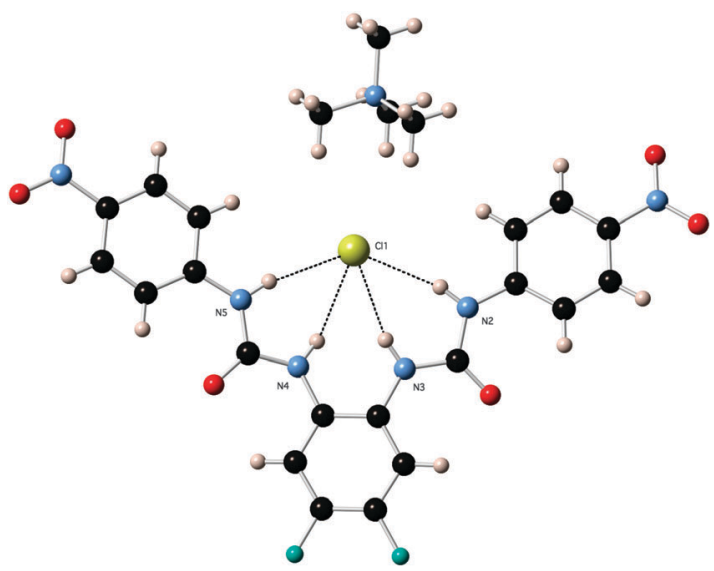

Fig. 2 X-ray crystal structure of 6.TMACl.

X-ray crystal structures of the chloride complexes of compounds 2 and 6 were elucidated using single crystal X-ray diffraction techniques. Crystals were obtained by slow evaporation from DMSO solutions (a mix with $\mathrm{MeOH}$ in the case of receptor 6) in the presence of an excess quantity of tetrabutylammonium chloride or tetramethylammonium chloride.

Receptor 2 was found to form a $2: 2$ receptor: anion complex in the solid state with tetrabutylammonium chloride $(\mathrm{N}-\mathrm{Cl}$ distances

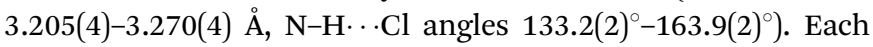
chloride anion is bound by four hydrogen bonds, two from each of the participating receptors (Fig. 1). Receptor 6 forms a 1:1 receptor : anion complex with chloride ( $\mathrm{N}-\mathrm{Cl}$ distances 3.205(2)3.315(2) $\AA, \mathrm{N}-\mathrm{H} \cdots \mathrm{Cl}$ angles $\left.151.5(1)^{\circ}-167.1(1)^{\circ}\right)$. The chloride anion is bound by each of the four possible hydrogen bonds from the receptor (Fig. 2).

Proton NMR anion-binding studies (Table 1) were conducted for receptors 1-7 with chloride, bicarbonate and nitrate anions, to determine their affinity and stoichiometry of binding. Stability constants, $K_{1}$, were determined by following the shift of the most deshielded $\mathrm{N}-\mathrm{H}$ proton and fitting the data to a $1: 1$ receptor: anion binding isotherm using WinEQNMR2. ${ }^{15}$

Stability constants measured for the interaction between the receptors and chloride are quite moderate (30-100 $\left.\mathrm{M}^{-1}\right)$. Many of the measured stability constants between the receptors and bicarbonate were very large, particularly that of receptor 3 $\left(>10^{4}\right)$, and in some cases the data could not be fitted to a binding isotherm due to peak splitting and broadening within the ${ }^{1} \mathrm{H}$ NMR spectra. This behaviour can be attributed to strong binding interactions and possible secondary equilibrium processes in solution. In general, the receptors did not significantly interact with nitrate anions, and the majority of the stability constants were measured at $<10 \mathrm{M}^{-1}$.

Anion transport studies were carried out for receptors $2,3, \mathbf{4}, \mathbf{6}$, 7 and prodigiosin 8 using vesicle based methods,${ }^{16}$ using the same procedures employed to study compounds $\mathbf{1}$ and $\mathbf{5}$ previously. ${ }^{2}$

To determine chloride/nitrate exchange transport capabilities a sample of unilamellar POPC vesicles were prepared containing $489 \mathrm{mM} \mathrm{NaCl}$ buffered to $\mathrm{pH} 7.2$ with $5 \mathrm{mM}$ sodium phosphate salts. The vesicles were suspended at a lipid concentration of $1 \mathrm{mM}$ in $489 \mathrm{mM} \mathrm{NaNO}$ buffered to $\mathrm{pH} 7.2$ with $5 \mathrm{mM}$ sodium phosphate salts. The experiment was initiated by the addition of a small amount of a DMSO solution of the receptor (mol\% with

Table $1 \mathrm{EC}_{50}$ (mol\%) values for receptor 1-8 for the release of chloride from POPC vesicles in $\mathrm{Cl}^{-} / \mathrm{NO}_{3}^{-}$and $\mathrm{Cl}^{-} / \mathrm{HCO}_{3}{ }^{-}$antiport systems at $270 \mathrm{~s}$ and $390 \mathrm{~s}$ respectively. $\mathrm{EC}_{50}$ values are the average of three runs, unless otherwise stated, and Hill coefficient $(n)$ values are also averaged. Stability constant $K_{1}\left(\mathrm{M}^{-1}\right)$ for receptors 1-7, measured in DMSO- $d_{6} / \mathrm{H}_{2} \mathrm{O} 0.5 \%$ at $298 \mathrm{~K}$. Guest anions $\mathrm{Cl}^{-}$and $\mathrm{NO}_{3}^{-}$were added as tetrabutylammonium salts, while $\mathrm{HCO}_{3}{ }^{-}$was added as the tetraethylammonium salt. Stability constants were determined by ${ }^{1} \mathrm{H} \mathrm{NMR}$ titrations following the most deshielded $\mathrm{N}-\mathrm{H}$ resonance. All data sets were fitted to a $1: 1$ receptor : anion binding isotherm using WinEQNMR2 ${ }^{15}$

\begin{tabular}{|c|c|c|c|c|c|c|c|}
\hline & $\mathrm{EC}_{50}{ }^{a}(\mathrm{~mol} \%) \mathrm{Cl}^{-} / \mathrm{NO}_{3}{ }^{-}$ & $n^{b} \mathrm{Cl}^{-} / \mathrm{NO}_{3}^{-}$ & $\mathrm{EC}_{50}{ }^{c}(\mathrm{~mol} \%) \mathrm{Cl}^{-} / \mathrm{HCO}_{3}{ }^{-}$ & $n^{d} \mathrm{Cl}^{-} / \mathrm{HCO}_{3}^{-}$ & $K_{1}, \mathrm{Cl}^{-i}\left(\mathrm{M}^{-1}\right)$ & $K_{1}, \mathrm{HCO}_{3}^{-i}\left(\mathrm{M}^{-1}\right)$ & $K_{1}, \mathrm{NO}_{3}{ }^{-i}\left(\mathrm{M}^{-1}\right)$ \\
\hline 2 & 0.0099 & 1.1 & 0.077 & 1.0 & 65 & & $<10$ \\
\hline 3 & $0.0015^{f}$ & 1.1 & 0.012 & 1.1 & 50 & $>10^{4}$ & $<10$ \\
\hline $5^{e}$ & 0.0048 & 0.9 & 0.038 & 1.1 & 78 & 7330 & $<10$ \\
\hline 6 & 0.0019 & 1.1 & 0.016 & 1.2 & 94 & $g$ & $<10$ \\
\hline 7 & $0.0016^{f}$ & 1.1 & 0.011 & 1.3 & & $g$ & $<10$ \\
\hline
\end{tabular}

${ }^{a}$ Concentration of receptor (mol\% receptor to lipid) required to achieve $50 \%$ chloride efflux at $270 \mathrm{~s}$ during the $\mathrm{Cl}^{-} / \mathrm{NO}_{3}{ }^{-}$exchange experiment.

${ }^{b}$ Hill coefficient for $\mathrm{Cl}^{-} / \mathrm{NO}_{3}{ }^{-}$exchange experiment. ${ }^{c}$ Concentration of receptor (mol\% receptor to lipid) required to achieve $50 \%$ chloride efflux at $390 \mathrm{~s}$ during the $\mathrm{Cl}^{-} / \mathrm{HCO}_{3}{ }^{-}$exchange experiment. ${ }^{d}$ Hill coefficient for $\mathrm{Cl}^{-} / \mathrm{HCO}_{3}{ }^{-}$exchange experiment. ${ }^{e}$ From previously published results. ${ }^{12}$

${ }^{f}$ Average of four runs. ${ }^{g}$ Data could not be fitted due to resonance broadening upon addition of anions. ${ }^{h}$ Data could not be adequately fitted to a binding model due to multiple equilibria in solution (see ESI). ${ }^{i}$ See ESI for errors in stability constants. 


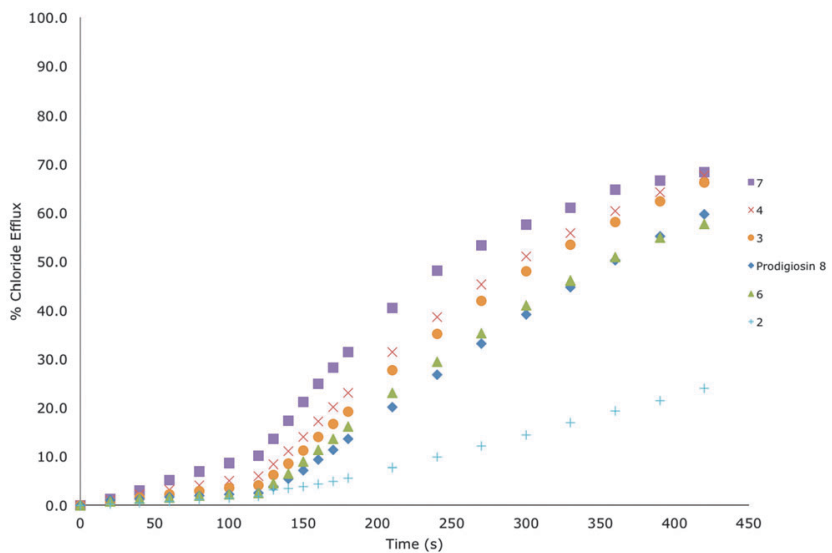

Fig. 3 Chloride efflux as a function of time, promoted by the addition of $0.02 \mathrm{~mol} \%$ (with respect to lipid) of receptors $2,3,4,6,7$ and prodigiosin 8 , from unilamellar POPC vesicles containing $451 \mathrm{mM} \mathrm{NaCl}$ buffered to $\mathrm{pH}$ 7.2 with $20 \mathrm{mM}$ sodium phosphate salts. The vesicles were dispersed in $150 \mathrm{mM} \mathrm{Na}_{2} \mathrm{SO}_{4}$ buffered to $\mathrm{pH} 7.2$ with $20 \mathrm{mM}$ sodium phosphate salts. The receptor was loaded as a DMSO solution at $0 \mathrm{~s}$, and a spike of $\mathrm{NaHCO}_{3}$ $(33 \mathrm{mM})$ added as $120 \mathrm{~s}$. At the end of the experiment the vesicles were lysed to calibrate the ISE to $100 \%$ chloride efflux.

respect to lipid), and the resulting chloride efflux was monitored using a chloride ion selective electrode (ISE). At the end of the experiment (300 s), the vesicles were lysed by adding a detergent, and the final electrode reading was used to calibrate $100 \%$ chloride release. Fig. 3 shows a comparison of the transport properties of receptors 1-8 (excluding $\mathbf{1}$ and 5) for chloride/bicarbonate antiport at $0.02 \mathrm{~mol} \%$ loading of transporter.

In order to determine the mechanism of chloride release by the receptors, we performed a second experiment using POPC vesicles containing $451 \mathrm{mM} \mathrm{NaCl}$ buffered to $\mathrm{pH} 7.2$ with $20 \mathrm{mM}$ sodium phosphate salts. The vesicles were suspended in $150 \mathrm{mM}$ $\mathrm{Na}_{2} \mathrm{SO}_{4}$ buffered to $\mathrm{pH} 7.2$ with $20 \mathrm{mM}$ sodium phosphate salts. On addition of a sample of receptor, there was little significant chloride release. This indicates that these receptors function by an anion exchange mechanism. In the first assay, the receptors were able to facilitate $\mathrm{Cl}^{-} / \mathrm{NO}_{3}{ }^{-}$exchange, but in this second experiment their activity was diminished due to the high hydrophilicity of the $\mathrm{SO}_{4}{ }^{2-}$ anion, ${ }^{17}$ which in most cases prevents its transport by synthetic transporters. ${ }^{18}$ After $120 \mathrm{~s}$, we added a pulse of $\mathrm{NaHCO}_{3}$ solution, and found that the receptors were mediating chloride efflux, evidence in support of the hypothesis that these receptors are also able to facilitate a $\mathrm{Cl}^{-} / \mathrm{HCO}_{3}{ }^{-}$ antiport mechanism.

In order to quantify these anion transport processes, we performed a Hill analysis for chloride/nitrate and chloride/ bicarbonate antiport by the receptors. ${ }^{19}$ These experiments allowed us to calculate the $\mathrm{EC}_{50}$ for these processes, a measure of activity defined as the effective receptor concentration required to mediate $50 \%$ chloride efflux after a specified time period. As is standard in our studies, this period is $270 \mathrm{~s}$ for chloride/nitrate experiments and $390 \mathrm{~s}$ for chloride/bicarbonate experiments (corresponding to $270 \mathrm{~s}$ after the $\mathrm{HCO}_{3}{ }^{-}$spike). We were also able to determine the Hill coefficient $(n)$, which can be used to give an indication of the number of monomers that form the active transport system. ${ }^{20}$ These values, and the previously reported data are shown in Table 1.

A study of retention times of the compounds by a reversed phase HPLC $^{21}$ showed that there is not a simple relationship between lipophilicity and the $\mathrm{EC}_{50}$ values of this series of compounds.

An increase in transport activity is observed when going from bis-urea receptor 1 to receptor 2 . These results may be rationalised by considering the effect of increased fluorination, ${ }^{10,22}$ in that receptor $\mathbf{2}$ is expected to have higher lipophilicity than receptor $\mathbf{1}$, and hence is expected to partition into the POPC membrane more effectively.

Receptors $\mathbf{3}$ and $\mathbf{4}$ are analogous to receptors $\mathbf{1}$ and 2 respectively, except that the central phenyl rings are fluorinated. Unlike their simpler counterparts, receptors 3 and 4 do not follow the same trend in activity. The $\mathrm{SF}_{5}$ containing compound 4 was found to be less active than the $\mathrm{CF}_{3}$ containing compound 3 for chloride/nitrate antiport. An efficacious transporter must strike a balance between aqueous solubility and lipophilicity to allow for successful delivery to the POPC vesicles and to allow partitioning into and out of the membrane to transport anions from one side of the membrane to the other. In the case of receptor 4, one possibility is that the balance of aqueous solubility and lipophilicity has been pushed too far in favour of lipophilicity, and so the receptor resides more within the membrane, hence chloride/nitrate transport is slightly hindered when compared to that of receptor 3 . The transport efficiency of $\mathbf{3}$ and $\mathbf{4}$ are roughly equal for chloride/bicarbonate antiport, but perhaps the most surprising thing here is that this seemingly minor structural change results in receptors that can outperform natural product prodigiosin, $\mathbf{8}$, at chloride/bicarbonate antiport (Table 1).

To explore this idea further we synthesised receptor 6 . Attaching additional electron-withdrawing fluorine substituents to the central ring boosts the transport properties of receptor 6 relative to receptor 5. In fact receptor 6 is almost 2.5 times better at promoting chloride/nitrate and chloride/bicarbonate antiport processes than the parent compound. However, unlike with receptors 3 and 4 , receptor 6 does not outperform prodigiosin 8 at chloride/bicarbonate antiport.

The strategy of introducing higher degrees of fluorination onto a receptor scaffold to enhance its transport properties is further illustrated by compound 7 which contains a fluorinated central ring and 3,5-bis(trifluoromethyl) substituents on its terminal phenyl rings. This compound has a lower $\mathrm{EC}_{50}$ value for chloride/bicarbonate exchange than prodigiosin 8 (Table 1) and is thus a more effective antiporter for this anion pair than the natural product (Fig. 3).

We have demonstrated that fluorinated receptors based on the bisurea motif are highly effective anion transporters and function by an antiport mechanism of anion transport. Modification of existing transporters, by adding fluorination at the central phenyl ring or by increasing fluorination at the peripheral phenyl groups, yielded highly potent anion transporters capable of surpassing the activity of the natural anion transporter prodigiosin, $\mathbf{8}$, for chloride/ bicarbonate exchange. This may be due to the affinity of the bisureas for carboxylates ${ }^{11}$ including bicarbonate. 
We thank the EPSRC for a studentship (LEK) and a postdoctoral fellowship (CJEH) (EP/J009687/1). PAG thanks the Royal Society and the Wolfson Foundation for a Royal Society University Research Merit Award. We thank Julie Herniman for conducting reverse phase HPLC on these compounds.

\section{Notes and references}

1 N. Busschaert and P. A. Gale, Angew. Chem., Int. Ed., 2013, 52, 1374-1382.

2 J. T. Davis, O. Okunola and R. Quesada, Chem. Soc. Rev., 2010, 39, 3843-3862; S.-K. Ko, S. K. Kim, A. Share, V. M. Lynch, J. Park, W. Namkung, W. Van Rossom, N. Busschaert, P. A. Gale, J. L. Sessler and I. Shin, Nat. Chem., 2014, DOI: 10.1038/nchem.2021.

3 S. Ohkuma, T. Sato, M. Okamoto, H. Matsuya, K. Arai, T. Kataoka, K. Nagai and H. H. Wasserman, Biochem. J., 1998, 334, 731-741.

4 T. Sato, H. Konno, Y. Tanaka, T. Kataoka, K. Nagai, H. H. Wasserman and S. Ohkuma, J. Biol. Chem., 1998, 273, 21455-21462.

5 J. L. Sessler, L. R. Eller, W.-S. Cho, S. Nicolaou, A. Aguilar, J. T. Lee, V. M. Lynch and D. J. Magda, Angew. Chem., Int. Ed., 2005, 44, 5989-5992. 6 J. L. Seganish and J. T. Davis, Chem. Commun., 2005, 5781-5783.

7 J. T. Davis, P. A. Gale, O. A. Okunola, P. Prados, J. C. IglesiasSánchez, T. Torroba and R. Quesada, Nat. Chem., 2009, 1, 138-144.

8 J. T. Davis, in Topics in Heterocyclic Chemistry, ed. P. A. Gale and W. Dahaen, Springer, New York, 2010, vol. 24, pp. 145-176.

9 J. A. Cooper, S. T. G. Street and A. P. Davis, Angew. Chem., Int. Ed., 2014, 53, 5609-5613; S. Hussain, P. R. Brotherhood, L. W. Judd and A. P. Davis, J. Am. Chem. Soc., 2001, 133, 1614-1617; P. R. Brotherhood and A. P. Davis, Chem. Soc. Rev., 2010, 39, 3633-3647.
10 N. Busschaert, M. Wenzel, M. E. Light, P. Igesias-Hernandez, R. PerezTomas and P. A. Gale, J. Am. Chem. Soc., 2011, 133, 14136-14148; N. Busschaert, I. L. Kirby, S. Young, S. J. Coles, P. N. Horton, M. E. Light and P. A. Gale, Angew. Chem., Int. Ed., 2012, 51, 4426-4430; N. Busschaert, R. B. P. Elmes, D. D. Czech, X. Wu, I. L. Kirby, E. M. Peck, K. D. Hendzel, S. K. Shaw, B. Chan, B. D. Smith, K. A. Jolliffe and P. A. Gale, Chem. Sci., 2014, 5, 3617-3626.

11 S. J. Brooks, P. R. Edwards, P. A. Gale and M. E. Light, New J. Chem., 2006, 30, 65-70; S. J. Brooks, P. A. Gale and M. E. Light, Chem. Commun., 2005, 4696-4698.

12 S. J. Moore, C. J. E. Haynes, J. Gonzalez, J. L. Sutton, S. J. Brooks, M. E. Light, J. Herniman, G. J. Langley, V. Soto-Cerrato, R. Perez-Tomas, I. Marques, P. J. Costa, V. Felix and P. A. Gale, Chem. Sci., 2013, 4, 103-117.

13 S. Altomonte and M. Zanda, J. Fluorine Chem., 2012, 143, 57-93; P. Kirsch, Modern Fluoroorganic Chemistry Synthesis, Reactivity, Applications, Wiley-VCH, Weinheim, 2004.

14 P. I. Hernández, D. Moreno, A. A. Javier, T. Torroba, R. Pérez-Tomás and R. Quesada, Chem. Commun., 2012, 48, 1556-1558.

15 M. J. Hynes, J. Chem. Soc., Dalton Trans., 1993, 311-312.

16 B. D. Smith and T. N. Lambert, Chem. Commun., 2003, 2261-2268.

17 Y. Marcus, J. Chem. Soc., Faraday Trans., 1991, 87, 2995-2999.

18 N. Busschaert, L. E. Karagiannidis, M. Wenzel, C. J. E. Haynes, N. J. Wells, P. G. Young, D. Makuc, J. Plavec, K. A. Jolliffe and P. A. Gale, Chem. Sci., 2014, 5, 1118-1127.

19 A. V. Hill, Biochemistry, 1913, 7, 471-480.

20 S. Bhosale and S. Matile, Chirality, 2006, 18, 849-856.

21 T. Braumann, J. Chromatogr. A, 1986, 373, 191-225.

22 N. Busschaert, S. J. Bradberry, M. Wenzel, C. J. E. Haynes, J. R. Hiscock, I. L. Kirby, L. E. Karagiannidis, S. J. Moore, N. J. Wells, J. Herniman, G. J. Langley, P. N. Horton, M. E. Light, I. Marques, P. J. Costa, V. Felix, J. G. Frey and P. A. Gale, Chem. Sci., 2013, 4, 3036-3045. 